\title{
The Technology of Co-Culturing of Potatoes with Honey Plants and Prospects of Its Technical Support
}

\author{
Ivan Voiku \\ Department of Business management \\ and innovation management \\ Pskov State University \\ (of Affiliation) \\ Pskov, Russia \\ voiku-ivan@yandex.ru
}

\begin{abstract}
The right way out of the crisis of the agrobased industries is the maximum use of the opportunities of scientific and technological progress and the orientation of the real economy to innovative development.

One of the promising technologies of crop production is an innovative technology in potato growing, which provides for the co-culturing of potatoes with honey crops.

Phacelia tanacetifolia (PhaceliatanacetifoliaBenth) is selected as honey crop, which is a valuable green manure. It allows to reduce the need for organic and mineral fertilizers, increases the ecological cleanness of products, favors the growth of potato yield, provides the additional honey yield.

Phacelia significantly improves the soil structure, displacing a significant part of weeds, providing natural loosening of the soil, protection from drying out, from pests and parasites. The co-culturing of potatoes with phacelia protects the environment from the use of dangerous plant protection products.
\end{abstract}

If the economic effect is defined as the difference between the profits of innovative and traditional technologies, then, according to preliminary calculations, the level of profitability of innovative technology in potato growing is 1.9 times higher, and the profit from 1 ha is $\mathbf{1 . 6}$ times higher compared with the traditional technology.

Large-scale development of the proposed technology is hampered by the lack of potato planters and seed planters, which provide planting of potatoes and sowing seeds of honey crops simultaneously, in the Russian market and the markets of the European Union.

An innovative technology - mounted seeder for potato planters was developed by the staff members of the Pskov State University. The article describes the main agrotechnological requirements to this device. A general model and a kinematic scheme were developed to visualize the combination of the working elements of the potato planter and the mounted seeder.

The developed model falls into the type of seed planters, which is designed to sowing in drills the seeds of honey crops (phacelia) in the furrow between potatoes at the time of the forthcoming closing of this furrow by soil, and can be used in agricultural engineering.

Potential consumers of the proposed innovative technology in potato growing and the developed mounted seeder are farm enterprises and agricultural production cooperatives, which have small plots of land, use crop rotation systems in potato growing, and work for reducing costs and increasing the yield of potato cultivation.

Keywords-device, effect, green manure, phacelia, potato growing, potato planter, seed planter, technology.

\section{INTRODUCTION}

Russia is the main potato producer in the world, occupying the first place in acreage, the second - in gross yield and one of the last places - in crop yield. The main reason for the low crop yield of this domestic culture is a significant lag behind the world agro-technological progress [1].

In order to increase competitiveness, the potato growing of Russia is trying to enter an innovationbased development: new varieties are established, high-production equipment is mastered, technology is improved, new types of fertilizers and plant protection products are used.

Review and analysis of traditional technologies of potato growing shows that they differ in the level of mechanization of work and a fairly wide range of technical equipments, and they are intended for farms with different production volumes. Analysis of potato production allows us to distinguish three systems of its cultivation: crop rotation, mixed sowing (planting) and monocultural [2]. The potato crop rotation system is used in large and medium-sized enterprises in field potato production, monocultural and mixed sowing (planting) - in small farms [3]. Technologies of co-culturing of potatoes with other crops: root vegetables, legumes, etc. are in use for a long time. However, the economic reserves of co-culturing of potatoes with honey crops have not yet been realized.

\section{MATERIALS AND METHODS}

In the course of the research, the object of which is the technology and technical support of potato cultivation, technological cards of traditional and proposed potato cultivation and harvesting have been developed to assess the effectiveness of innovative technologies. The costs of the previous year for future harvest are included in technological cards. According to the traditional technology, the forecrop is vetch and oat mixture. According to the new technology, the forecrop is phacelia [4]. 
Phacelia tanacetifolia (PhaceliatanacetifoliaBenth) is selected as honey crop, which is a valuable green manure. It allows to reduce the need for organic and mineral fertilizers, increases the ecological cleanness of products, favors the growth of potato yield, provides the additional honey yield [5].

\section{RESUlTS AND DISCUSSION}

Innovations, which allow to increase the soil fertility and yield of potatoes and to get the maximum profit at minimum cost, are much-needed in potato growing. We offer an innovative technology of co-culturing of potatoes with valuable honey plant - phacelia. Phacelia is a very valuable green manure. Plowed in, green mass (approximately 200 hundred kilograms per hectare) is equivalent to an application of 20 tons/ha of humus. Biomass accumulation is 343 hundred kilograms per hectare, including green mass - 317 hundred kilograms per hectare, root residues - 26 hundred kilograms per hectare. Phacelia does very well on almost any type of soil, enriches them with nitrogen and potassium compounds [6].

The list of technological operations of potato production according to the traditional technology is: loading and application of organic fertilizers; autumn plowing; sorting of potatoes; closing of moistness; application of mineral fertilizers; cultivating with harrowing; potato planting with pretreatment; spraying of potato plantings against annual, dicotyledonous and cereal weeds; loosening with harrowing; hilling; mowing of the tops with its mandatory removal from the field; mechanized harvesting of potatoes; transportation of potatoes to the place of storage.

The technological operations for spraying against weeds, Phytophthora and Colorado potato beetle are excluded, if potatoes are co-culturing with honey plants. But an additional work like sowing phacelia, hand weeding of potatoes and collecting Colorado beetles is requires.

Following scheme of sowing of potatoes with phacelia in agricultural enterprises is suggested: 2 or 4 rows (ridges) of potatoes, 2 or 4 ridges of phacelia. In such cases, phacelia can be sown in June after hilling or the last loosening of potatoes, and it can be plowed in like green fertilizer after harvesting of potatoes.

In households and small peasant (farm) enterprises with limited land resources phacelia can be sown in the spacing. It is also possible to use phacelia as a universal organic fertilizer three times during one season. Sowing of phacelia is possible: in the early spring period (before planting of potatoes); together with potatoes in a hole; additional autumn sowing of phacelia, which will form the third fresh yield on green manure until the autumn cold.

Considering the weak supply of organic fertilizers to agricultural enterprises, green-manure pairs are provided in crop rotation system. For these purposes, an area is scattered with vetch-oat mixture, white mustard with spring vetch or hairy vetch, green masses of which are plowed in. The use of phacelia as a green manure is more promising, as it allows quickly and cheaply to enrich the soil with organic matter and biological nitrogen. It significantly increases the yield of crops, reduces deseases of potatoes and vegetables, reduces a content of nitrates and heavy metals in products [7]. In general, this green manure crop increases crop productivity by 15 $20 \%$ while improving product quality.

Phacelia is a reliable defender of a soil from drying out, erosion, deep freezing [8].

When mixed sowing, phacelia significantly reduces a damage to the main crop by various species of fir seed moth, caterpillars and other pests, repels wireworms and locusts. In addition, phacelia prevents viral and fungal diseases on neighboring plants and subsequent crops in the crop rotation [9].

Fertilizer costs are $19-21 \%$ in the cost structure per 1 ha of potato-growing enterprises. The introduction of the proposed innovative technology will allow enterprises to significantly reduce costs on this item.

In addition, up to $20-30 \mathrm{~kg}$ of pollen and 200 to 500 $\mathrm{kg}$ of honey can be obtained from 1 ha of phacelia. This is beneficial to enterprises engaged not only in crop production, but also beekeeping [6].

Calculation of the economic efficiency of implementation of the proposed technology is determined by the example of a conventional agricultural producer engaged in or planning to be engaged in beekeeping. Acreage, yield, productivity, gross output, level of marketability and others are used as basic indicators (Table I).

TABLE I.

Calculation of the ECONOMiC EFFiciency of the inNovative POTATO PRODUCTION TECHNOLOGY.

\begin{tabular}{|c|c|c|}
\hline \multirow{2}{*}{ Indicators } & \multicolumn{2}{|c|}{ Technology } \\
\hline & traditional & innovative \\
\hline Acreage in total, ha: & 10 & 10 \\
\hline including Potatoes & 10 & 5 \\
\hline Phacelia & 0 & 5 \\
\hline $\begin{array}{l}\text { Yield of potatoes, hundred kilo- } \\
\text { grams per hectare }\end{array}$ & 200 & 200 \\
\hline Bees productivity, $\mathrm{kg} / \mathrm{ha}$ & 0 & 200 \\
\hline \multicolumn{3}{|l|}{ Gross output: } \\
\hline Potatoes, tons & 200 & 100 \\
\hline Honey, $\mathrm{kg}$ & 0 & 3000 \\
\hline \multicolumn{3}{|l|}{ Level of marketability, \% } \\
\hline Potatoes & 82 & 82 \\
\hline Honey & 0 & 95 \\
\hline $\begin{array}{l}\text { Cost of commercial products, in } \\
\text { total, RUB, in thousands: }\end{array}$ & 1640 & 1675 \\
\hline including Potatoes & 1640 & 820 \\
\hline Honey & 0 & 855 \\
\hline Costs in total, RUB, in thousands: & 1170 & 946 \\
\hline including Potatoes & 1170 & 917 \\
\hline Honey & 0 & 29 \\
\hline Profit, in total, RUB, in thousands & 470 & 729 \\
\hline Level of profitability, $\%$ & 40 & 77 \\
\hline $\begin{array}{l}\text { Economic effect, RUB, in } \\
\text { thousands }\end{array}$ & & 259 \\
\hline
\end{tabular}


The economic effect is defined as the difference between the profits of innovative and traditional technologies. According to our calculations, the level of profitability of the innovative technology is 1.9 times higher, the profit from 1 ha is 1.6 times higher and the total economic effect amounts to 259 thousand rubles compared with the traditional technology.

The proposed allocation of a part of the cultivated area under potatoes for phacelia is very conditional. The use of the innovative technology of potato cultivation can significantly "condense" the crop rotation, increasing the area under potatoes and reducing it under complete fallow.
The spread of this technology and its widespread use by potato-growing agricultural enterprises require the development of mechanization in sowing of phacelia while planting of potatoes.

The research of the functional purpose and technical characteristics of some popular models of potato planters and seed planters allows us to draw the following conclusion: in the domestic and foreign markets there are no potato planters, providing simultaneous planting of potatoes and sowing of seeds of honey crops (Table II).

TABLE II.

FUNCTIONAL PURPOSE OF POTATO PLANTERS AND SEED PLANTERS.

\begin{tabular}{|c|c|c|c|c|c|}
\hline \multirow[b]{2}{*}{ Name } & \multirow[b]{2}{*}{$\begin{array}{c}\text { Country of manu- } \\
\text { facture }\end{array}$} & \multicolumn{4}{|c|}{ Performed functions } \\
\hline & & $\begin{array}{l}\text { Planting } \\
\text { potatoes }\end{array}$ & Fertilization & $\begin{array}{c}\text { Application of } \\
\text { insecticides/ } \\
\text { Pretreatment }\end{array}$ & $\begin{array}{l}\text { Planting seeds } \\
\text { (including com- } \\
\text { bined culture) }\end{array}$ \\
\hline \multicolumn{6}{|c|}{ Potato planters } \\
\hline Harrison & USA & + & + & + & - \\
\hline Grimme(GL) & Germany & + & - & + & - \\
\hline Hassia/Structural & Holland & + & + & - & - \\
\hline RBS/Multiplant & France & + & + & - & - \\
\hline Bomet & Poland & + & + & - & - \\
\hline SKN-2a & Russia & + & + & - & - \\
\hline SKN-4, L-201, L-207 & Belarus & + & + & - & - \\
\hline \multicolumn{6}{|c|}{ Seed planters } \\
\hline SZMP-4 & Russia & - & + & - & + \\
\hline SPCH-6L & Russia & - & + & - & + \\
\hline STV & Belarus & - & + & - & + \\
\hline
\end{tabular}

The seed planters, used by enterprises, combine no more than two functions: sowing seeds and fertilizing [10]. Therefore, development of a principally new device is essential for realization of the economic reserves of co-culturing of potatoes with honey crops [11].

The model, developed by the staff members of the Pskov state University, is a mounted assembly unit, including: a hopper for phacelia seeds, with two rigid conical hoses that contain gates. A state of the gate is regulated by the mechanism connected with the photocells, which are fixed on the lower end of the planting device of the potato planter [12].
The developed model falls into the type of seed planters, which is designed to sowing in drills the seeds of honey crops (phacelia) in the furrow between potatoes at the time of the forthcoming closing of this furrow by soil (Fig. 1), and can be used in agricultural engineering.

The conical transfer devices, driven by a belt drive from the additional pulley, which is located on an axle of the potato planter, are fixed on rigid hoses. The disk, which contains the holes in a certain order for sowing the phacelia seeds and is connected with a rigid hose, is driven by the transfer device.

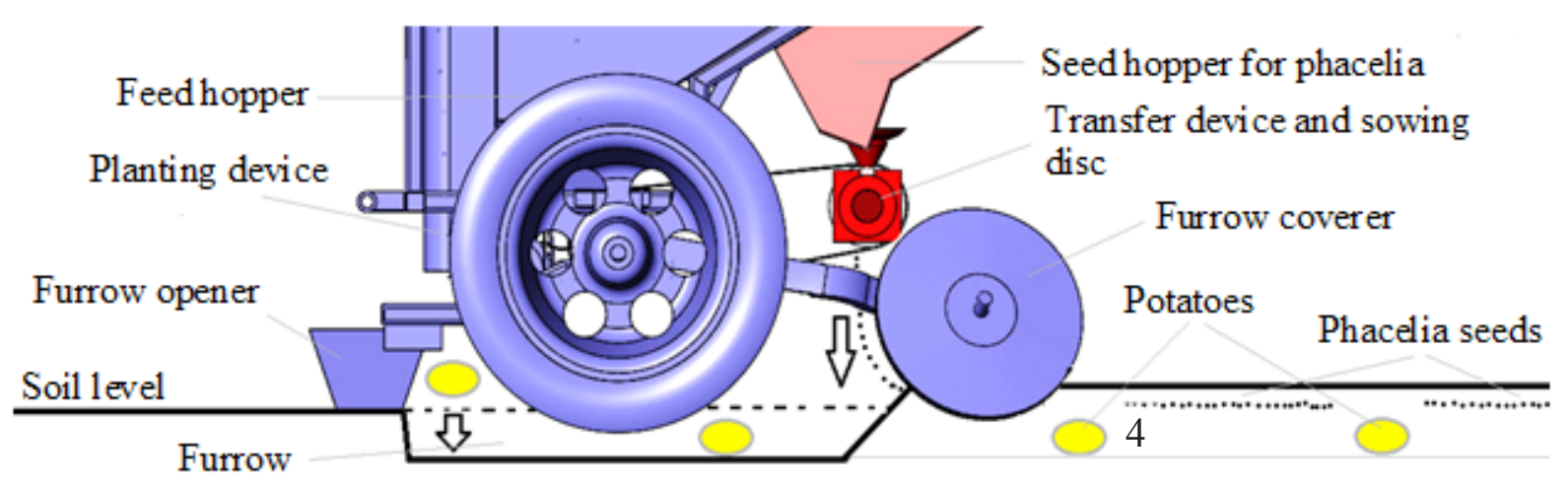

Fig. 1. Technological scheme of the combined model (potato planter and seed planter). 
The main agro-technological requirements to the developed model are:

- $\quad$ uniform flow of seeds in dispersing disc;

- $\quad$ ensuring sustainable seeding through time;

- $\quad$ no damage to seeds;

- $\quad$ closing of seeds by a moist layer of soil;

- $\quad$ possibility of long-term usage.

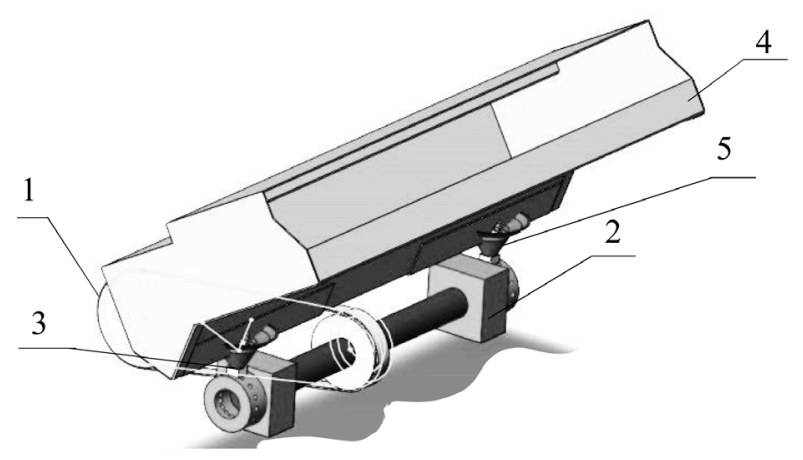

Fig. 2. General view of the mounted seeder.
Conventional symbols of the belt drive (1), the conical transfer device (2) and the feed disc (3) are used to explain the principle of the mounted seeder in the kinematic scheme (Fig. 2).

The mounted seeder for potato planter operates in the following manner. After loading the potatoes and seeds in the appropriate hoppers a tractor operator is starting from rest, a turning torque from driving wheels of the potato planter is transmitted to the shaft of the seeder through a belt drive (1).

Conical transfer devices with sowing discs are situated on the shaft of the seeder (2). The conical transfer device transmits the rotation to the disc,

reducing the rotation speed. When a signal is received from a photocell, a hopper gate (3) opens and the seeds from a honey crop hopper (4) get in a rigid conical hose (5) and then into the center of the sowing disc. The disc has holes, through which the seeds fall into the soil.

The general model (Fig. 3a) and the kinematic scheme (Fig. 3b) are developed to visualize the combination of the working elements of the potato planter and the mounted seeder. Figure 3a shows: the components of the potato planter in blue color, mounted seeder in red color.

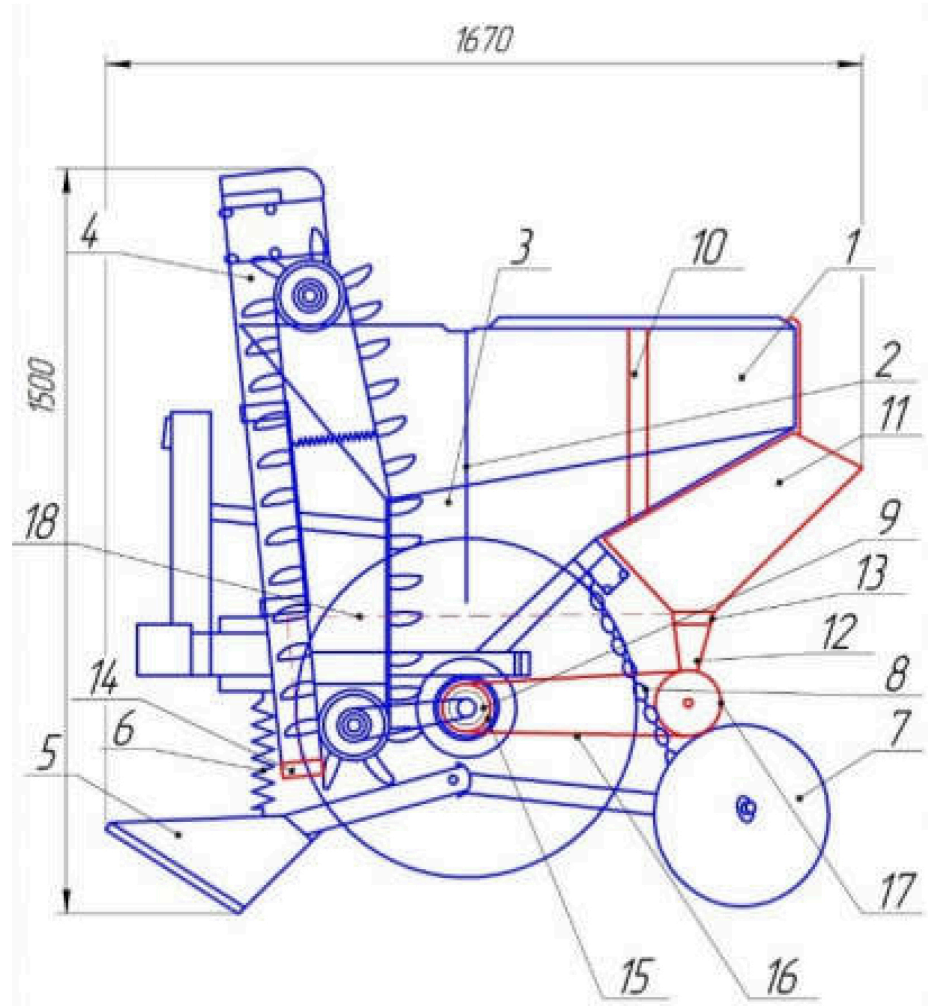

a

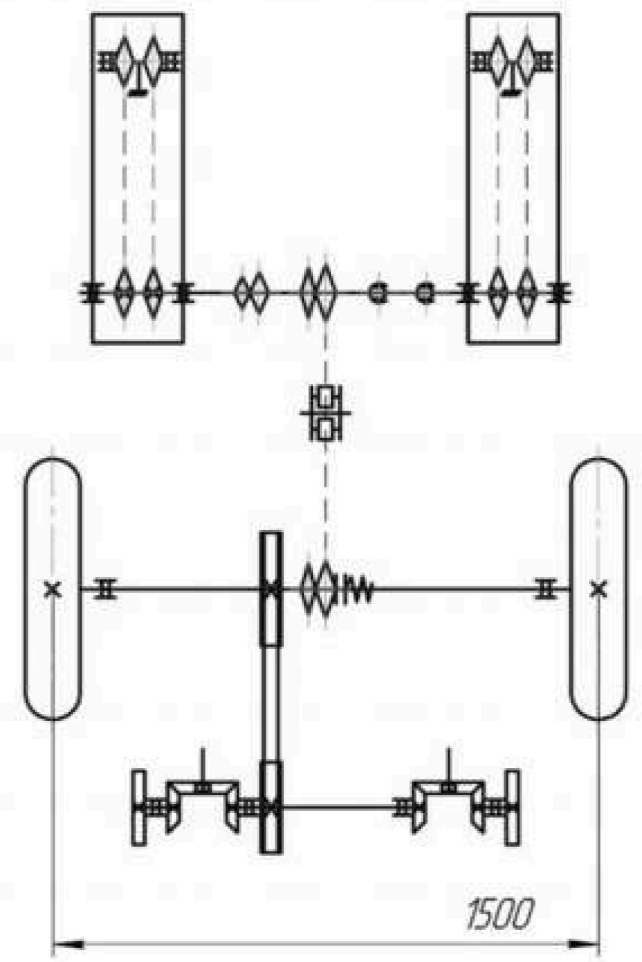

b

Fig. 3. The model (a) and the kinematic scheme (b) of combination of the potato planter and the seeder.

Symbol names of the model elements are presented in Table III. 
TABLE III.

SPECIFICATION OF THE COMBINED MODEL.

\begin{tabular}{|c|l|l|l|l|l|}
\hline Position & \multicolumn{1}{|c|}{ Assembly unit } & Number & Position & \multicolumn{1}{c|}{ Assembly unit } \\
\hline 1 & Hopper & 1 & 10 & Rigid attachment of mounted seeder & 2 \\
\hline 2 & Hopper gate & 1 & 1 & 11 & Seed hopper for phacelia \\
\hline 3 & Feed hopper & 2 & 12 & Rigid conical hose & 1 \\
\hline 4 & Planting device & 2 & 14 & Hopper gate & 2 \\
\hline 5 & Furrow opener & 2 & 15 & Additional pulley \\
\hline 6 & Tine of furrow opener & 2 & 16 & Belt & 2 \\
\hline 7 & Furrow coverer & 2 & 17 & Conical transfer device \\
\hline 8 & Round-link chain & 1 & 18 & Cable & 2 \\
\hline 9 & Drive with supporting wheels & & 2 \\
\hline
\end{tabular}

The kinematic scheme is a graphical scheme of working units and blocks of a construction's mechanism [13]. The schematic kinematic scheme shows the sequence of transmission of motion from an engine through an intermediate mechanism to working elements of the device and their relation.

\section{Conclusions}

Thus, the right way out of the crisis of the agro-based industries is the maximum use of the opportunities of scientific and technological progress and the orientation of the real economy toward an innovative development.

One of the promising technologies of crop production is the innovative technology in potato growing, which provides for the co-culturing of potatoes with honey crops. It is developed by the staff members of the Pskov State University.

Phacelia tanacetifolia (PhaceliatanacetifoliaBenth) is selected as a honey crop, which is a valuable green manure. It allows to reduce the need for organic and mineral fertilizers, increases the ecological cleanness of products, favors the growth of potato yield, provides the additional honey yield.

The substantiation of necessity and expediency of introduction of the innovative technology in potato growing of the region is given; the execution sequence of technological operations of the proposed technology is presented; the advantages of co-culturing of potatoes and the most valuable honey plant - phacelia are described; the economic effect from introduction of the innovative technology is calculated.

Large-scale development of the proposed technology is hampered by the lack of potato planters and seed planters, which provide planting of potatoes and sowing seeds of honey crops simultaneously, in the Russian market and the markets of the European Union.

The innovative technology - the mounted seeder for potato planters is developed by the staff members of the Pskov State University. The article describes the main agro-technological requirements to this device. The general model and the kinematic scheme are developed to visualize the combination of the working elements of the potato planter and the mounted seeder.

The developed model falls into the type of seed planters, which is designed to sowing in drills the seeds of honey crops (phacelia) in the furrow between potatoes at the time of the forthcoming closing of this furrow by soil, and can be used in agricultural engineering. The scientific novelty of this model is the combination of work of two working devices simultaneously (potato planter and planter for sowing seeds of honey crops), which had never been combined before.

Potential consumers of the proposed innovative technology in potato growing and the developed mounted seeder are farm enterprises and agricultural production cooperatives, which have small plots of land, use crop rotation systems in potato growing, and work for reducing costs and increasing the yield of potato cultivation.

\section{REFERENCES}

[1] I.P. Voiku, A.A. Efimova, and E.A. Aleksandrov, "Effectiveness of the technology of co-culturing of potatoes with honey plants," Review of the International Academy of agricultural education, no. 18 , vol. 2 , pp. 20-25, 2013.

[2] M. Schrama, J. de Haan, M. Kroonen, H. Verstegen, and W.H. Van der Putten, "Crop yield gap and stability in organic and conventional farming systems," Agriculture, Ecosystems and Environment, no. 256, pp. 123-130, 2018. 10.1016/j.agee.2017.12.023.

[3] A.P. Ruposhev, "Innovative development of potato growing," Agro XXI, no. 4-6, pp. 8-10, 2012.

[4] B. Amoabeng, A. Johnson, and G. Gurr, "Natural enemy enhancement and botanical insecticide source: a review of dual use companion plants," Applied Entomology and Zoology, 2019. 10.1007/s13355-018-00602-0.

[5] R. Mallinger, J. Franco, Jr, D.A. Prischmann-Voldseth, and J. Prasifka, "Annual cover crops for managed and wild bees: Optimal plant mixtures depend on pollinator enhancement goals," Agriculture, Ecosystems and Environment, no. 273, pp. 107-116, 2019. 10.1016/j.agee.2018.12.006.

[6] M.M. Gluhov, "Honey plants." Moscow: Kolos, 1974.

[7] J. Kátai, T. Döring, M. Tállai, A. Kovács, I. Henzsel, M. Makádi, Z. Sándor, and I. Vágó, "Influence of alternative plant nutrition methods on soil microbial characteristics in long-term experiments," Agrochemistry and Soil [AgrokémiaésTalajtan], no. 67, pp. 79-90, 2018. 10.1556/0088.2018.67.1.6.

[8] Z. Demir, N. Tursun, and D. Işik, "Effects of Different Cover Crops on Soil Quality Parameters and Yield in an Apricot Orchard," International Journal of Agriculture and Biology, no. 21, 2018

[9] S. Savary, L. Willocquet, S. Jane Pethybridge, P. Esker, N. McRoberts, and A. Nelson, "The global burden of pathogens and pests on major food crops," Nature Ecology and Evolution, no. 1, 2019. 10.1038/s41559-018-0793-y.

[10] W. Sun, X. Liu, H. Zhang, H. Wang, and B. Tian, "Design of potato casingsoil planter in all-in-one machine combined with fertilizing, sowing, ridging, complete film mulching and planting line covering," Transactions of the Chinese Society of Agricultural Engineering [Nongye Gongcheng Xuebao], no. 33, pp. 1422, 2017. 10.11975/j.issn.1002-6819.2017.20.002.

[11] F. Rathore, and S. Chaturvedi, "Development and performance evaluation of manually operated Potato planter," Bhartiya Krishi Anusandhan Patrika, 2018. 33. 10.18805/BKAP121.

[12] I.P. Voiku, and T.V. YAkovleva, "Mounted seeder for potato planters L-201 and L-207," Tractors and agricultural machinery, no. 1, pp. 15-17, 2015.

[13] V.N. Ozherelyev, and F.N. Kotikov, "Sprouted Potato Tuber Dynamics and Kinematics during Mechanized Planting," Procedia Engineering, no. 206, pp. 56-60, 2017. 10.1016/j.proeng.2017.10.437. 